\title{
Increasing biogas production from sugar cane baggase by anaerobic co-digestion with animal manure
}

\author{
Siswo Sumardiono ${ }^{1, *}$, Aldi Budi Riyanta ${ }^{1}$, Hashfi Hawali Abdul Matin ${ }^{2}$, Tutuk Djoko Kusworo ${ }^{1}$, Bakti Jos $^{1}$, and \\ Budiyono ${ }^{1}$ \\ ${ }^{1}$ Department of Chemical Engineering, Diponegoro University, 50275 Semarang, Indonesia \\ ${ }^{2}$ Department of Environmental Engineering, Diponegoro University, 50275 Semarang, Indonesia
}

\begin{abstract}
The result of this research is to determine the ratio of the combination of cow manure and bagasse (F/I) to the volume of biogas production, chemical pretreatment effect of raw material bagasse on biogas production volume and the effect of co-digester on biogas production. The results showed a decrease in total solid occurs when the increase of $2 \%, 5 \%$ to $10 \%$, and this contributes to decreasing the production of biogas. Chemical pretreatment influences on the production of biogas through pretreatment with $2 \% \mathrm{NaOH}$ solution with surface morphology bagasse seen with SEM image and its chemical structure changes with FTIR instrument. The highest biogas yield of $51.04 \mathrm{~L} / \mathrm{Kg}$ substrate was obtained from a combination bagasse treated with $2 \% \mathrm{NaOH}$ solution for 24 hours and as much as $20 \%$ cow's rumen.
\end{abstract}

\section{Introduction}

Utilization of non-renewable energy in excess can cause problems of energy crisis [50]. The use of energy sources such as fuel derived from fossil raw materials is a fuel that is not easily recyclable and requires a long process to produce the fuel. Therefore, there are the needs for new alternative energy sources that can be updated [48]. One of the energy technologies that comply with these requirements is biogas technology $[16,40]$.

Production of biogas from waste and organic residue with various types of anaerobic digesters method has been widely studied, both experimental and theoretical, for six decades [32].This material raw biogas can be obtained from lignocellulosic biomass and a wide range of organic wastes there are animal waste, industrial waste water and municipal solid wastes [5, 47]. Availability of lignocellulose raw materials are abundant in the world make lignocellulose into raw materials most in demand for biofuel production [46].

Biogas production has been carried out by several researchers. Biogas obtained by performing a combination of water hyacinth and sheep dung. A ratio of $4: 12.01: 83.90$ between the hyacinth : sheep dung : water produces biogas production as much as $0.361 / \mathrm{g}$ $[37,52]$, in his journal did a combination of grass Pakchong with chicken manure at a ratio of $50: 50 \%$ produce methane $0.27 \pm 0.01 \mathrm{~L} / \mathrm{Kg}$ VS. Oleszek [36] comparing the production of biogas from weeds and grass varieties of walnuts. The study resulted in that canary grass produces more biogas for $406 \mathrm{~N} . \mathrm{dm}^{3} / \mathrm{kg} \mathrm{VS}$ than 120 varieties of wild grass $\mathrm{N} . \mathrm{dm}^{3} / \mathrm{Kg} \mathrm{VS}$ ).
Bagasse is a lignocellulosic waste from sugar mills and agricultural processing [33]. Bagasse, like other lignocellulosic materials, has three main components: cellulose, hemicellulose and lignin [41]. Lignocellulose is composed of cellulose, hemicellulose and lignin [58]. Cellulose and hemicellulose has a long chain of sugar monomers and can be converted into bioenergy through pretreatment and hydrolysis [38]. Bagasse has a main constituent named xylose. Xylose $\left(\mathrm{C}_{5} \mathrm{H}_{10} \mathrm{O}_{5}\right)$ is a monosaccharide that is generated from the hydrolysis of hemicellulose in the form of xylan. Xylose also known as wood sugar as it contained in the timber -rich hemicellulose [17].

Pretreatment can increase the total yield of methane [24]. Pretreatment component initial pretreatment of biomass used as a first step to hydrolysis. This stage, complex organic molecules are broken down until get smaller components such as simple sugars, amino acids, and fatty acids. Most of the studies, conducted using alkali and acid pretreatment. Alkali used as $\mathrm{NaOH}$ applied to biomass pretreatment process. This makes the components of lignocellulose undergo solvation and saponification reaction components made of porous lignocellulose into the entrance of the enzyme [26]. Using acid pretreatment is also carried by [55], to break down lignocellulose component in water hyacinth.

The reform process anaerobic organic matter to biogas formation is influenced by two factors, namely, biotic and abiotic. Biotic factor such as microorganisms. Abiotic factors include: the substrate, the water content of the material/substrate, the ratio of $\mathrm{C} / \mathrm{N}$ and $\mathrm{P}$ in the material / substrate, temperature, aeration, presence of toxic (poisonous elements), $\mathrm{pH}$ and stirring. So that the

* Corresponding Author: siswo.sumardiono@che.undip.ac.id 
raw material (substrate) with a high $\mathrm{C} / \mathrm{N}$ ratio (lignocellulose) compared with low $\mathrm{C} / \mathrm{N}$ ratio (cow dung) gives the average composition corresponding input ratio desired levels [42]. Then, the condition of the anaerobic digestion process is maintained in equilibrium and dynamic conditions [39] Anaerobic co-digestion process becomes an important solution. To obtain a good digestion process needs to do a combination of the co-digestion. Co-digestion which combine with agricultural waste, animal dung to obtain the high biogas production and to achieve a $\mathrm{C} / \mathrm{N}$ ratio ideal [52]. $\mathrm{C} / \mathrm{N}$ ratio is 20-30 base that allows the process of digestion and biogas production is high. If the $\mathrm{C} / \mathrm{N}$ ratio is high (60) biogas production will be small. Meanwhile, C/N ratio is low (10) also experienced a slow process [1].

\section{Materials and methods}

\subsection{Raw material and inoculum}

Bagasse as raw material obtained from sugar factory in Central Java Jatibarang Brebes. It dried for a week, then milled and sieved to the size of $0.85 \mathrm{~mm}$ (22 mesh) [2]. Inoculum used was the rumen of cows and cow dung obtained in slaughterhouses Jatibarang, Brebes in Central Java.

\subsection{Batch Anaerobic Digestion}

This study uses a batch digester 5 Liter with a working volume 2 Liter. Biomass raw material for laboratoryscale experiments are bagasse (AT). Characteristics \% TS (total solids), \% VS (volatile solids) from a variety of biomass used are shown in Table 1. with the addition of $2 \% \mathrm{NaOH}$ solution then do the treatment for 24 hours and 48 hours besides sugarcane bagasse there is no treatment. Juntarasiri et al [26] reported, the addition of $\mathrm{NaHCO}_{3}$ is used to get neutral $\mathrm{pH}$ of the raw material before process. Table 1 shows the baseline characteristics of each sample.

Table 1. Types of initial biomass feedstock

\begin{tabular}{|l|c|c|c|}
\hline \multirow{2}{*}{\multicolumn{1}{c|}{$\begin{array}{c}\text { Types of } \\
\text { Biomass }\end{array}$}} & \multicolumn{3}{c|}{ Characteristics } \\
\cline { 2 - 4 } & TS \% & VS \% & VS/TS \\
\hline Bagasse & 79,64 & 78,83 & 0,99 \\
\hline Cow dung & 16,67 & 13,17 & 0,79 \\
\hline AT* & 79,07 & 77,00 & 0,97 \\
\hline AT** & 78,50 & 76,83 & 0,98 \\
\hline Rumen's cow & 26,50 & 14,33 & 0,54 \\
\hline
\end{tabular}

Raw materials and cow manure is fed to the digester with each variation of the ratio F/I 2, 5, 10\% (base TS) to form slurry. Water added to the volume of work. Experiments were performed at room temperature.
Digester was closed with a rubber stopper and one end of the hose was inserted inside each digester. Measuring cup was placed on the stand and clamp to measure the volume of biogas by water - displacement methods [4]. Biogas volumes were measured 2-3 days during 84 days trial of anaerobic co-digestion process.

\subsection{Analytical methods}

Biogas volume is measured by water displacement method. TS and VS concentration was measured using a standard method [4]. While the $\mathrm{pH}$ was measured using a $\mathrm{pH}$ stick by dissolving $5 \mathrm{~g}$ of sample into $50 \mathrm{~mL}$ of water. Cellulose and lignin content of the bagasse is determined by the Chesson method. Biogas composition were analyzed using Gas Chromatography.

\section{Results and discussion}

\subsection{Effect of chemical pretreatment of the volume of biogas}

Pretreatment before anaerobic digestion process has proven to be one simple and effective method to increase the biodegradability and biogas yield from lignocellulose materials [23].

Figure 1 shows the surface bagasse as seen in SEM image. Bagasse is undergoing treatment with $\mathrm{NaOH} 2 \%$ by immersing bagasse for 24 and 48 hours. The structure of the surface morphology bagasse more open as shown in the sample B1 and $\mathrm{C} 1$ which each experienced a magnification of 500x, addition of alkali can make swell lignocellulose components [30, 34]. Treatment with $2 \% \mathrm{NaOH}$ solution on the bagasse components, such as lignin and hemicellulose will dissolve leaving a smooth surface along with the fiber [26]. This shows that most of the carbohydrate components such as lignin, hemicellulose, which is the skin surface has been dissolved by $\mathrm{NaOH}$ solution, so few will react with cellulose [51]. Natrium hydroxide also serves to change the structure of the composition of pure bagasse [22].

FTIR spectra (Figure 2) shows that a change in the concentration of hydroxyl functional groups of each bond is on bagasse. This indicates that the $\mathrm{OH}$ bond existed at the bagasse react with $\mathrm{Na}$ ion this case proved the value of the absorbance spectra $\mathrm{B}$ and $\mathrm{C}$ are reduced. FTIR spectra comparison indicated there was a picture where the sample A at figure 2. Bagasse without treatment and bagasse with treatment for 24 hours and 48 hours with sample $\mathrm{B}$ and $\mathrm{C}$ treated by $\mathrm{NaOH} 2 \%$. 

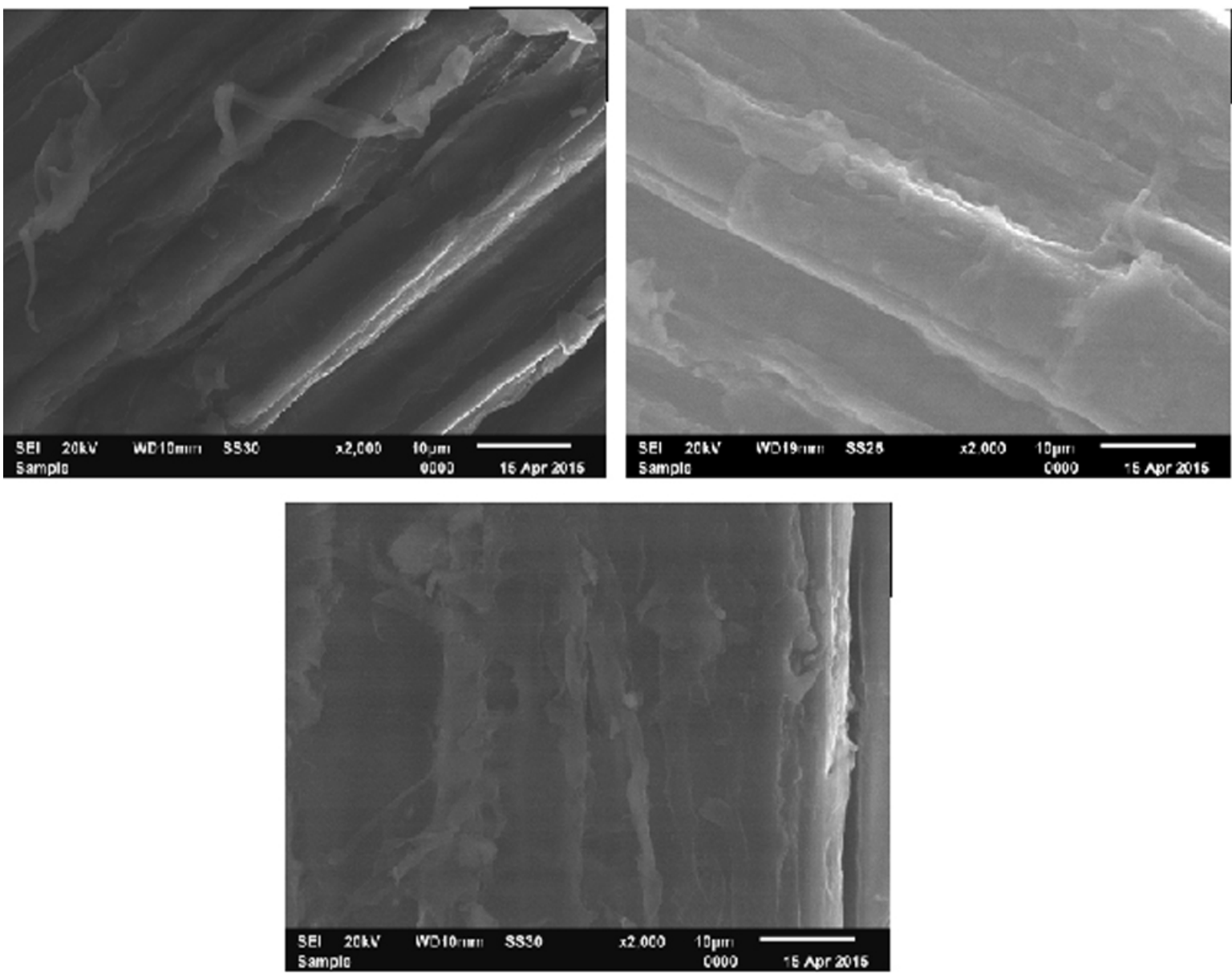

Fig 1. SEM image of bagasse of bagasse without treatment (A), bagasse undergo treatment with $\mathrm{NaOH} 2 \%$ for 24 hours (B), and bagasse undergo treatment with $\mathrm{NaOH} 2 \%$ for 48 hours (C).

Visible spectra are at wavelengths of more than 1200 cm-1 [49]. Structural differences have given evident with the addition of alkali $(\mathrm{NaOH})$ as a treatment. The spectra are shown in the display wavelengths 3400-3500 $\mathrm{cm}-1$. It shows the culmination (reduction) of the $-\mathrm{OH}$ functional groups. Peak around $2920 \mathrm{~cm}-1$ appears there stretching of $\mathrm{CH}$. Peak seen appear on down at the wavelength of $1049 / \mathrm{cm}$. Bagasse spectra at $2920 / \mathrm{cm}$ (Figure 2. (A)) are stretching from $\mathrm{CH}_{2}$ and down at a wavelength of 2901/cm (Figure 2. (B)) and 2851/cm (Figure 2. (C)) after a delignification process [33].

Biogas volume data is presented as a daily and cumulative biogas yield during the 84-days trial, as shown in Figure 3. Figure 3. (a) shows the volume of biogas daily on TS content of $2 \%$ and $20 \%$ cow's rumen co-digester with P1 is made of bagasse biogas without going through the treatment process, P4 bagasse with 24 hours of immersion treatment using $\mathrm{NaOH} 2 \%$ [26] and P7 is bagasse before being fed into the reactor treatment performed by soaking for 48 hours using a $2 \% \mathrm{NaOH}$.

Biogas started to be measured on the second day in a row and its volume was measured every other day. Measurement of the second day to day to twenty volumes of biogas continues to rise and gain first peak with $\mathrm{P} 1$ on day 16 amounted to $1.678 \mathrm{~L} / \mathrm{Kg}$ Substrate,
P4 amounted to $6.298 \mathrm{~L} / \mathrm{Kg}$ Substrate on day 50, while P7 reached its peak the highest biogas volume on day 56 with a volume of $5.825 \mathrm{~L} / \mathrm{Kg}$ Substrate. Figure 4. (a) it appears that no treatment effect in the acquisition of the volume of biogas.

Experiment P1 is a combination bagasse coupled with rumen as a maid in the process of digestion is seen that the highest volume at day 16 was as described González [19]. This period is the period of a single substrate. Peaks occur because the day 10 to 20 a period of single substrate. More digestible substrate will produce in advance compared to the substrate is more difficult to degrade. Rumen is a substrate that is easier to digest. Rumen bacteria contains ruminant [11]. Which is able to degrade cellulose in biomass materials. In addition to the treatment process is also a delignification process, a number of lignin will be dissolved.

This process is a process of saponification of the intermolecular ester bond that surrounds xylan, Hemicellulose and other components, like lignin and hemicellulose more. Delignification processes causing damage to the structure of lignin and release carbohydrate compound [51]. 


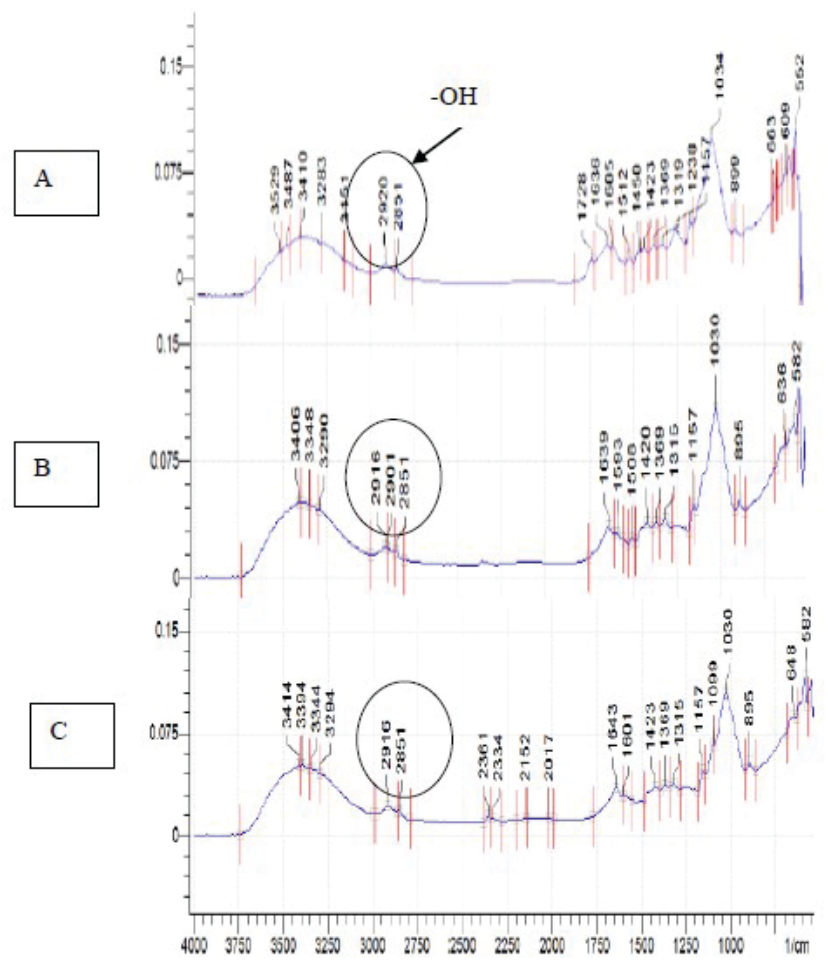

Fig 2. FTIR Spectra of bagasse without treatment (A), bagasse undergo treatment with $\mathrm{NaOH} 2 \%$ for 24 hours (B), and bagasse undergo treatment with $\mathrm{NaOH} 2 \%$ for 48 hours (C).

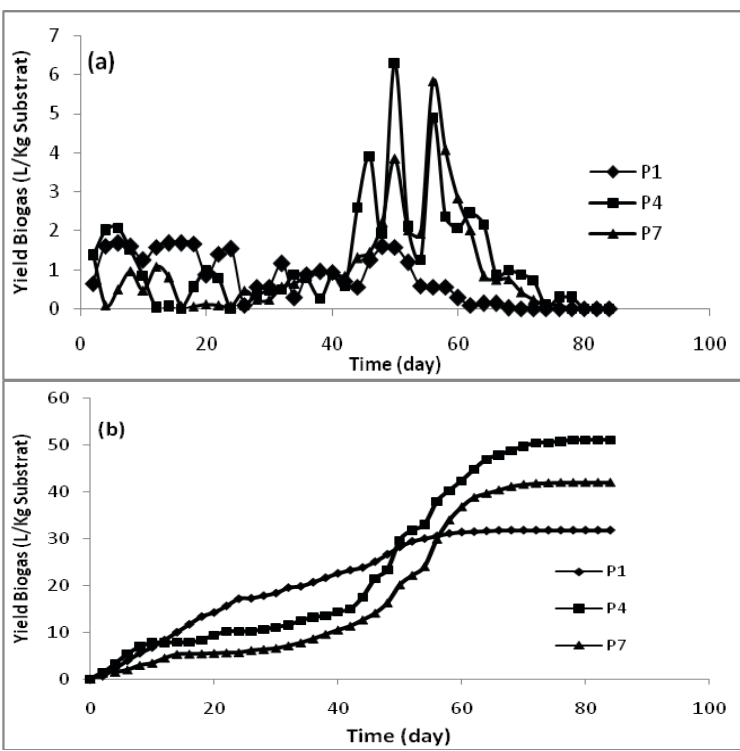

Fig 3. The volume of biogas with variations of pretreatment and total solids (TS) $2 \%$ (a) the volume of daily biogas P1, P4 and P7 (b) Volume of cumulative biogas P1, P4 and P7

\subsection{Influence of total solid content (TS)}

This study will show the content of TS which affects the production of biogas. Variations of total solid used is $2 \%, 5 \%$ and $10 \%$. Yield of biogas is presented in the form of biogas and volume of data accumulated by the cumulative length of time during the 84 -day trial (Figure 4.).

Experiment P1, P2 and P3 are each using TS 2\%, $5 \%$, and $10 \%$ and using a cow rumen inoculum as much as $20 \%$ of the working volume of two liters. Experiment P1, P2 and P3 biogas yield is calculated on the second day as on the first day no biogas is produced. Biogas yields continue to rise from the start to the second day up to nine reached the top first and then the volume continues to fall until day 35 . Yield biogas and then rise again until day 40 to day 56 reached the top of the second and achieved a higher volume than the first peak. Experiment P1 and P3 have a similar pattern in the biogas yield accumulation. P2 has a graph which charts more gentle than the graph $\mathrm{P} 1$ and $\mathrm{P} 3$. The highest volume of biogas obtained in P2 on day 44 with a volume of $1.45 \mathrm{~L} / \mathrm{Kg}$ Substrate, P1 on day 46 with a volume of $1.68 \mathrm{~L} / \mathrm{Kg}$ Substrate and P3 on day 56 with a volume of $0.68 \mathrm{~L} / \mathrm{Kg}$ Substrate. Accumulated biogas yield obtained at $\mathrm{P} 1$ reaches $31.78 \mathrm{~L} / \mathrm{Kg}$ substrate, $\mathrm{P} 2$ as much as $18.89 \mathrm{~L} / \mathrm{Kg}$ Substrate, and P3 as many 13.10 $\mathrm{L} / \mathrm{Kg}$ Substrate. P1 experiments using bagasse as much as $2 \% \mathrm{TS}$ and use co-digester rumen viewed from the observation experiment $\mathrm{P} 1$ is the highest compared with $\mathrm{P} 2$ and P3. Figure 4.shows the production of biogas P1, $\mathrm{P} 2$ to $\mathrm{P} 3$ tends to decrease with increase in the content of total solids (TS). With the condition that the higher the total solid of reducing the amount of substrate on anaerobic co-digestion system, so that components with high substrate will easily degradable organic components [25]. 


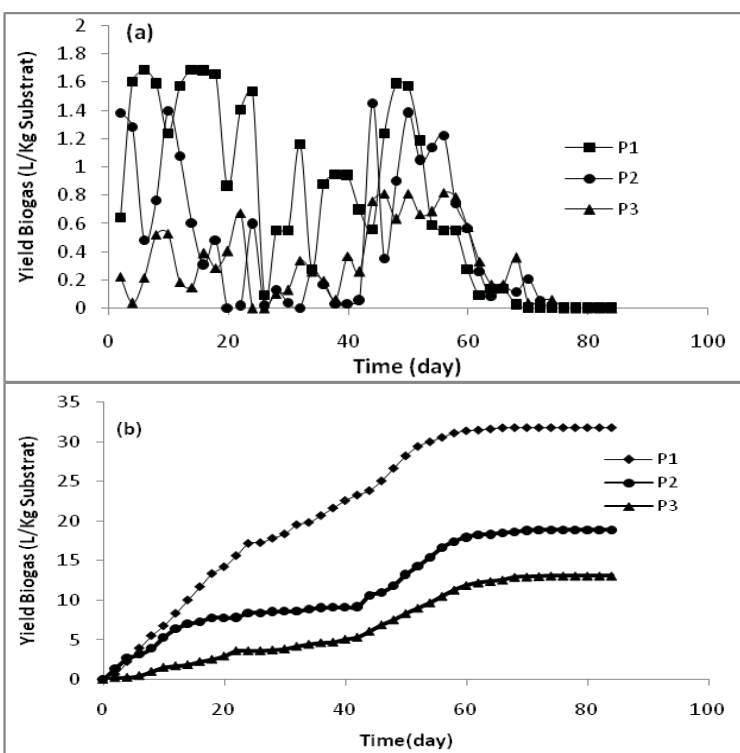

Fig 4. Yield of biogas in the variation of TS content of $2 \%, 5$ $\%, 10 \%$ (a) $=$ P1, P2, P3 co-digester cow rumen without treatment; (b) Yield biogas accumulation of P1, P2, P3.

Results of this research together with research conducted by [26] with the lowest cumulative biogas yield is obtained at a high TS content during the process of digestion of sewage sludge. Statistical analysis also showed the content of TS has a significant affect the biogas production [15].

The content of TS is too high causing the speed of production of organic acids in the early stages faster than the speed of digestion of acid consumption by methanogenic bacteria [25] This of course causes the activity of methanogenic bacteria is inhibited and decreases the production of biogas [31].

The content is too high TS can also occur in the inhibition process of hydrolysis process because of the low $\mathrm{pH}$ [31]. Microbial activity with the raw materials to be difficult because of the limited space resulted in mass transfer process is inhibited. The products of hydrolysis phase collected on the surface of the substrate and ultimately inhibits the absorption of hydrolytic enzymes. Mass transfer is limited to make the number of products available for microbial acidogenic hydrolysis slightly so will reduce product on acidogenesis processes which will be converted into biogas [43].

\section{Conclusions}

Biogas production on bagasse with treatment processes better than the production of biogas in the bagasse without treatment. Biogas production on bagasse best on the total solid $2 \%$ compared to the total solid higher $5 \%$ and $10 \%$. The most optimum biogas production contained in the bagasse treated with $\mathrm{NaOH} 2 \%$ for 24 hours and the cow rumen co-digester with maximum biogas production rate of $6.3 \mathrm{~L} / \mathrm{kg}$.day and total production of biogas of $51.04 \mathrm{~L} / \mathrm{kg}$.
The authors thank to Diponegoro University via International Research and Publication (Riset Publikasi Internasional, RPI) Grant 2016 for financial support.

\section{References}

1. Achmad, K.T.B., Hidayati, Y.A., Fitriani, D., Imanudin, O. Lucrări Științifice - vol. 55, Seria Zootehnie (2015)

2. Anief, M. Gadjah Mada University Press (2010)

3. Akwaka, J.C., Kukwa, D.T. \& Mwekave, S.S. International Journal of Science and Technology, 3(4), pp.222-228 (2014)

4. APHA, Standard Methods for the Examination of Water and Wastewater Part 1000. Book: American Public Health Association, American Water Works Association, Water Environment Federation (2005)

5. Brown, D., Shi, J. \& Li, Y. Bioresource Technology, 124, pp.379-386 (2012)

6. Budiyono., Syaichurrozi, I.,Sumardiono, S.. IJE Transactions B: Applications. 27, No. 2, pp 177184 (2014)

7. Budiyono, Widiasa, I.N., Johari, S and Sunarso. Energy Research Journal 1 (1): pp 6-11 (2010)

8. Budiyono, Widiasa I.N., Johari S., Sunarso. World Academy of Science, Engineering and Technology, 37:983-988 (2010)

9. Budiyono, I. Syaichurrozi, S. Sumardiono. World Applied Sciences Journal 26 (11): 1464-1472 (2013)

10. Budiyono, Iqbal S., Siswo S. Research Journal of Applied Sciences, Engineering and Technology 7(3):2798-2805 (2014)

11. Budiyono, I. Syaichurrozi and S. Sumardiono. International Journal of Engineering, 27(2):177184 (2014)

12. Budiyono, S. Sumardiono and D. Tri Mardiani. International Journal of Engineering, 28(2): 921928 (2015)

13. Budiyono, I N. Widiasa, S. Johari, and Sunarso. International Journal of Engineering and Technology, 1(3):109-116, ISSN : 0975-4024 (2009)

14. Burak. D., Scherer P., Yenigun O., Onay T. Environmental Science and Technology, 40:116$146(2010)$

15. Carneiro, Y.F., Perez, M., Romero, L. I.,. Bioresorce Technology, 99 pp 6994-7002 (2008)

16. Darsin, M. Design of Biogas Circulator, Seminar Nasional Kreativitas Mesin Brawijaya 2006, Universitas Barawijaya, Malang (2006)

17. Faisal, A.. Skripsi: Universitas Indonesia (2008)

18. Gaudet, M.M., Agnew, J., Fonstad, T.A.,. In the Canadian Societyu for bioengineering / La Societe Canadiene de Genie Agroalimentaire. Paper No. CSBE13-027 (2013)

19. González, L.M., Castro, R., Pereira, M.A., Alves, M.M., Font, X., Vicent, T.,. Bioresource Technology 102 pp 4734-4741 (2011)

20. Hassan, R., International Water Technology Journal, IWTJ (2014) 
21. Hussein, I., Abdel-Shafy, A., Mona, S.M., Mansour. Egyptian Petroleum Research Institute pp xxx-xxx (2014)

22. Hatakka, A. Biodegradation of lignin. University of Helsinki, Viikki Biocenter, Department of Applied Chemistry and Microbiology (1994)

23. He, Y., Pang, Y., Liu, Y. P., Li, X., Wang, K., Department of Environmental Science and Engineering, and Center for Resources and Environmental Energy \& Fuels, 22, pp 27752781 (2008)

24. Hendriks, A.T.W.M. \& Zeeman, G.,. Bioresource Technology, 100, pp.10-18 (2009)

25. Jha, A.K., Li, J., Zhang, L., Ban, Q., Jin, Y., Advances in Water Resource and Protection, 1(2), pp 28-38 (2013)

26. Juntarasiri, P. S. Nijsunkij, T. Buatick, E. Jamkrajang, S. Wacharawichanant,M. Seadan, A. Wasantakorn and S. Suttiruengwong. Enhancing. Energy Procedia 9 pp 207 - 215 (2011)

27. Kangle, K.M. Kore, S. U. Kore. U.S. G. S, Kulkurni.,. Universal Journal of Environmental Research and Technology, 2(4), pp.210-219 (2012)

28. Kim, M., Yang, Y., Morikawa, Sakura M.S., Wang, Q., Lee M.V., Lee D.Y., Int J Hydrogen Energy; 37: pp 3142-9 (2012)

29. Kim, M., Liu, C., Noh, J.W.,Yang, Y., Oh, S., Shimizu, K., Lee, D.Y., Zhang, Z., International journal of hydrogen energy $3 \mathbf{8}$ pp 8648-8656 (2013)

30. Kong, F., Engler, C., Soltes,. Applied Biochemistry and Biotechnology pp 34-35, pp 23-35 (1992)

31. Li, Y., Zhu, J., Wan, C., Park, S.Y.,. American Society of Agricultur and Biological Engineers, 54(4), 1415-1421 (2011)

32. Marek, M. Bialobrzewski, I. Zielinski, M. Debowski, M. Krzemienewski, M.,. Renewable Energy, 69 pp.219-225 (2014)

33. Maryana, R, Ma'rifatun, D. A. Wheni, Satriyo K.W., W. Rizal. A. Energy Procedia, 47 pp $250-$ 254 (2014)

34. Montgomery, L.F.R., Bochmann, G.,. Book. IEA Bioenergy. British Library. ISBN 978-1-91015405-2 (electronic version) (2014)

35. Mshandete, A., Bjornson, L., Kivaisi, A.K., Rubindamayugi,M.S.T., Mattiasson, B.,. Renewable Energy, 31, 2385-2392 (2005)

36. Oleszek, M. Krol, A. Jerzy, T. Matyka, M. Kulik, M. Bioresource Technology 156 pp 303-306 (2014)

37. Patil, H. J. Raja, M. A. L. A. Raja, S. B.B. Shettyc, M. K. B. P.Kumard, P.. Energy Procedia 52 pp $572-578$ (2013)
38. Petersson, A. Mette, H.T. Nielsen, H.H. Thomson, A.B. Biomass and Bioenergy, 31, pp.812-819 (2007)

39. Putri, D.A. Saputro, R.R. Budiyono., Biogas Production from Cow Manure. Int. Journal of Renewable Energy Development 1(2) pp 61-64 (2012)

40. Putro, Sartono, Laporan. Vol .10, No. 2 : 178 188 (2007)

41. Rabelo, S.C. H. Carrere. Maciel, F.R. Costa. A.C.. Bioresource Technology 102 pp. 78877895 (2011)

42. Sasongko, W. Tesis : Universitas Sebelas Maret (2010)

43. Sheets, J.P., Ge, X., Li, Y., Bioresource Technology, 144, pp 296-303 (2015)

44. Song, Z., Yang, G., Han, X., Feng, Y. Z., Ren, G., BioMed Research International Vol. 2013 Article ID 968692, pp 9 (2012)

45. Tao, Y. (He et al.). Z.; Guan, Y. T. J. Cell. Sci. Technol. 2003, 11 (1), 42-55 (in Chinese) (2008)

46. Teghammar, A., Evaluation. Thesis: Chalmers University of Technology (2013)

47. Tuesorn, S. Wong, W.S. Champreda, V., Bioresource Technology, 144, pp.579-586 (2013)

48. Ukpai, P.A. \& Nnabuchi, M.N.,. Advances in Applied Science Research, 3(3), pp.1864-1869 (2012)

49. Vivekanand, V., Olsen. E.F., Eijsink, V.G.H., Horn, S.J.,. BioResource (9)1. Pp 1311-1324 (2014)

50. Wahyuni, Sri,. Kongres Ilmu Pengetahuan Nasional (KIPNAS) ke 10 (2011)

51. Weizhang Z, Zhang Z, Qiao W, Fu P, and Liu M. Renewable Energy; 36: 1875-9 (2011)

52. Wilawana, W. P. Pholchanb, and P. Aggarangsia. Energy Procedia 52 pp 216 - 222 (2014)

53. Yadvika, Santosh, Sreekrishnan, T.R., kohli, S., Rana, V., Bioresource Technology, 95, 1-10 (2004)

54. Yavini, T.D. Usman, H. T. Mohammed, N and James, M. Namo. The International Journal Of Engineering And Science, 3(2), pp.1-6 (2014)

55. Yonathan, A., Prasetya, A.R. Pramudono, B. Jurnal Teknologi Kimia dan Industri, Vol 2, No 2. Pp 211-215 (2013)

56. Zhang, R., Zhang, Z., Bioresource Technology, 68(3), 235-245 (1999)

57. Zheng, Yi, Jia Zhao, Fuqing Xu, Yebo Li., Progress in Energy and Combustion Science xxx 1-19 (2014)

58. Zhu, J., Wan, C. \& Li, Y., Bioresource Technology, 101(19), pp.7523-7 (2010) 